closely the internal structure of diamond than that of silicate minerals. How common that is, or whether it is most of ten seen in inclusions that have a similar crystallography to diamond, such as garnet, is unknown, but when present it is regarded as compelling evidence that the diamonds and inclusions are truly cogenetic. Further studies are necessary to clarify the relationship between inclusion morphology and the structural complexities of diamond, but it seems likely that both the inclusions and the diamonds worked on by Richardson $e t$ al. ${ }^{1}$ are 3,200-3,400 Myr old.

These ages are consistent with the observation that diamond-containing kimberlites only occur in old continental areas. The implication is that most diamonds are old, which is perhaps surprising and certainly prompts speculation as to why that might be. One suggestion is that diamonds are confined to old areas because it is only beneath those portions of the continental crust that the lithosphere is thick enough to extend to the depths where diamonds are stable $^{9}$. But why should the lithosphere that stabilized in the Archaean be thicker than that formed more recently?

An alternative approach is to seek a chemical explanation. The carbon content of the mantle was presumably greater early in Earth history than at present. Thus, enrichment processes that scavenge and concentrate trace elements in the upper mantle ${ }^{10}$ would have generated much higher localized concentrations of carbon in the Archaean than in recent times. We believe that the distribution of natural diamond $^{2}$, and its extremely old ages ${ }^{1}$, is more likely to be related to the high carbon content in the Archaean mantle than to differences in lithosphere thickness. Some diamonds appear to have been derived from recycled 'crustal' carbon ${ }^{6}$, and we speculate that these are the ones most likely to yield younger (post-Archaean) ages.

1. Richardson, S.H. et al. Nature 310, 198 (1984),

2. Gurney, J.J. \& Harte, B. Phil. Trans. R. Soc. A297, 273 (1980).

3. Boyd, F.R. \& Nixon, P.H. Phys. Chem. Earth 9, 431 (1975).

4. Davies, G.F. Earth planet. Sci. Lett. 44, 231 (1979).

5. Deines, P. Geochim. cosmochim. Acta 44, 943 (1980).

6. Milledge, H.J. et al. Nature 303, 791 (1983).

Swart, P.K. et al Nature 303, 793 (1983).

. Mattey, D. et al. Nature (submitted).

. B F R 64,341 (1983).

10. Hawkesworth, C.J. et al. Nature (in the press).

Nick Rogers and Chris Hawkesworth are in the Department of Earth Sciences, The Open University, Milton Keynes MK7 6AA.

\title{
Ecology
}

\section{Rise and fall of palsa mounds}

\section{from Peter D. Moore}

THE peat bogs of high latitudes, where the mean annual air temperature is $-1{ }^{\circ} \mathrm{C}$ and the annual precipitation is less than 400 $\mathrm{mm}$, are characterized by irregular peatcovered mounds with ice cores, called palsas ${ }^{1}$. The interaction of the climatic, biological and geomorphological factors involved in the initiation and growth of these mounds has provided a rich area for speculation, but one in which experimental data have been conspicuously absent. Now, however, experiments on a bog in the north of Finland by Seppala ${ }^{2-4}$ have provided a firm basis for the understanding of palsa mound ecology.

Palsa mounds are normally $2-4 \mathrm{~m}$ high, though some may reach as high as $7 \mathrm{~m}$ in the Fennoscandian mires ${ }^{5}$. They can be seen to pass through a cycle of growth followed by collapse when the ice core melts and leaves a water-filled crater surrounded by a peaty rampart. Salmi has suggested that palsas began their existence during periods of unusually cold climatic conditions, and has provided palynological data from Finnish palsas, accompanied by radiocarbon dates, which indicate two periods of palsa formation, around 7,000 and 5,000 b.p. (ref.6). But many palsa mires contain young developing palsa hummocks and the idea that initiation has been restricted to certain times in the past has not received general acceptance.

From their work on Canadian palsas, Railton and Sparling have produced an attractive theory of palsa growth and collapse based on the botanical succession which takes place on the elevated peat mass $^{7}$. They found that as the ice core raises the peat surface to about $60 \mathrm{~cm}$, changes in hydrological conditions encourage the invasion of small hummocks covered with Sphagnum fuscum by Cladonia lichens. They suggest that lichens have a considerable influence on the albedo of the mire surface; their white colour reflects such a high proportion of the incident radiation that the likelihood of summer melting of the ice core decreases and the palsa mound is allowed to grow more rapidly, aided by the high insulating properties of the drying peat blanket over its surface. Ultimately, the peat cover begins to erode as a result of wind action, and the disruption of surface vegetation exposes the dark-coloured peat with its low albedo. Summer absorption of radiation soon results in the rapid decay of the ice core and the collapse of the palsa.

The theory is very plausible and is supported by data on the albedo of the different vegetation types. But it lacks conviction, mainly in its explanation of the early stage of palsa formation simply as the development of a Sphagnum moss hummock. It is here that Seppala's proposals may fill the gap. Seppala has produced microclimatic data on the ground temperatures in the Arctic regions of Finland which show that frost penetration is far greater where the snow cover is least ${ }^{3}$. He also finds that the basal ice that forms when frost penetrates to a depth of over $50 \mathrm{~cm}$ on a bog survives the following summer and provides a nucleus for further ice formation in the subsequent winter ${ }^{4}$. Those parts of a bog surface which are kept free of snow as a result of wind action might, therefore, provide promising locations for the initiation of new palsa mounds.

As an experimental test of his proposal, Seppala selected a flat unfrozen area of a palsa mire in northern Finland and installed temperature probes to a depth of 2 $m$ into the peat at two sites. During the first winter, one site was experimentally cleared of snow on thirteen occasions, whereas on the control site the snow depth reached 90 $\mathrm{cm}$. At the experimental site, frost penetrated $80 \mathrm{~cm}$ into the peat and, although the surface layers thawed during the following summer to a depth of $40 \mathrm{~cm}$, the underlying $30 \mathrm{~cm}$ remained frozen throughout. At the control site, the winter frost only penetrated between 40 and $48 \mathrm{~cm}$, not enough to maintain an ice core in the peat through the summer months. During the second winter, snow clearance was carried out eight times at the experimental site and frost penetration reached $1 \mathrm{~m}$; a $50 \mathrm{~cm}$ thick ice core survived the following summer. The experiment continued for a third year and the ice continued to thicken.

The three years provided sufficient time for a palsa mound to begin to develop. The surface of the experimental site was $10 \mathrm{~cm}$ above the mire surface after one year, 20 $\mathrm{cm}$ after two years and $30 \mathrm{~cm}$ after three years. This was sufficient to produce some changes in vegetation, with the Sphagnum mosses and the cyperaceous plants becoming moribund as a result of summer drought. The surface peat was cracking, but there was no sign of lichen or shrub invasion. Interestingly, however, Seppala noted that the incipient palsa was lightly coloured, which could indicate that Railton and Sparling's changes in albedo were commencing.

This experimental approach to the study of palsas has demonstrated that differential snow lie on the mire surface can result in the initiation of a palsa mound, and that the development of such a mound acts as a positive feedback to the process because it further decreases snow lie on the developing hummock. Vegetation changes then account for the further processes which result in the cyclical system of palsa growth and decay.

Ruuhijarvi, R. Ann. bot. Soc. fenn. Vanamo 31, 1 (1960). Seppala, M. Proc. 4th Can. Permaforst Conf., 36 (1982). Seppala, M. Oulanka Rep. 4, 20 (1983)

Seppala, M. Permafrost: Proc. 4th int. Conf., 1127 (Washington, DC, 1983).

Ruuhijarvi, R. in Ecosystems of the World. Mires: Swamp, Bog, Fen and Moor Vol. 4B (ed. Gore, A.J.P.) 47 (1983). Salmi, M. Proc. 3rd int. Peat Conf. Ouebec, 182 (1968). Railton \& Sparling Can. J. Bot. 51, 1037 (1973).

Peter D. Moore is Senior Lecturer in the Department of Plant Sciences, King's College, 68 Half Moon Lane, London SE24 9JF. 